\title{
Unclear causes for subduction
}

To the Editor - Whether subduction initiation is a forced or spontaneous process is a fundamental geological problem. Using drill core data from the Amami Sankaku basin, Arculus et al. ${ }^{1}$ suggest that subduction in the Izu-Bonin-Mariana arc began spontaneously. Here we argue that the evidence presented favours neither spontaneous nor forced initiation.

Some numerical models predict that the early stages of forced subduction initiation cause uplift, then subsidence, followed by extension and seafloor spreading in the upper plate $e^{2,3}$. The seafloor spreading generates juvenile oceanic crust in the upper plate as the subducting plate sinks and subduction becomes self-sustaining ${ }^{2-4}$. A similar process of juvenile crust generation is proposed for spontaneous subduction initiation ${ }^{4}$. Early uplift, however, is not expected in spontaneous initiation because there is no contraction that precedes subduction. Thus, determining whether uplift occurred prior to subduction can test for spontaneous versus forced initiation. To test for uplift, one must sample crust that was present when uplift occurred.

Arculus et al. ${ }^{1}$ find that the age and geochemistry of the basement rocks at site U1438 resemble juvenile fore-arc basalts of the Izu-Bonin-Mariana subduction system formed from seafloor spreading at the early stages of subduction initiation ${ }^{4}$. Their new findings suggest that the extent of across-strike juvenile crust formation at the onset of subduction in the nascent Izu-Bonin-Mariana system is larger than previously thought. However, the presence, nature and/or spatial extent of the juvenile oceanic crust are currently not known to be different between a forced and spontaneous subduction initiation event and thus cannot be used to argue for one mode over the other. In addition, since the younger juvenile crust will not record the uplift expected to accompany forced initiation, Arculus et al. ${ }^{1}$ were not able to use sedimentological evidence to test for early uplift in pre-subduction initiation basement rocks. We conclude that the data presented by Arculus et al. ${ }^{1}$ do not favour spontaneous or forced subduction initiation at the Izu-Bonin-Mariana arc.

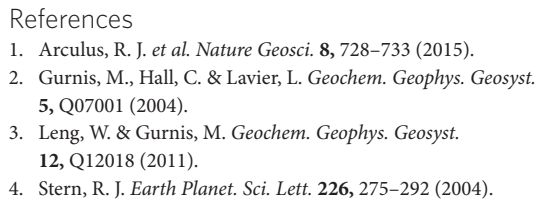

Timothy E. Keenan` and John Encarnación Department of Earth and Atmospheric Sciences, Saint Louis University, St. Louis, Missouri 63108, USA.

*e-mail: keenante@slu.edu

\section{Reply to 'Unclear causes for subduction'}

Arculus et al. reply - Keenan and Encarnación suggest that the absence of pre-subduction inception basement in the drill core data taken from site U1438 raises ambiguity in our conclusion of spontaneous subduction initiation in the Izu-Bonin-Mariana system ${ }^{1}$. However, there is no evidence for uplift in the earliest products of the Izu-Bonin-Mariana system preceding rifting preserved anywhere in the region. Three sub-parallel ridges from north to south, the Amami plateau, Daito and Oki-Daito ridges (Fig. 1 from ref. 1) - comprise magmatic products of Mesozoic-Tertiary arcs formed prior to the Izu-Bonin-Mariana system. These ridges generally strike east-west orthogonally to the Kyushu-Palau ridge the earliest stratovolcano chain of the Izu-Bonin-Mariana system. If compression preceded inception, as implied by the forced subduction model $^{2}$, we anticipate uplift of the old arc ridges, diminishing in effect westwards, and sediment shedding from uplifted regions into adjacent basins.

None of these predicted effects are observed. The Amami plateau, Daito and Oki-Daito ridges do not shallow eastwards, rather they shallow westwards ${ }^{3}$, possibly due to subsidence of the eastern sectors following inception of the Izu-Bonin-Mariana system $^{4}$. Crustal thicknesses change rapidly across-strike of the ridges, showing no east-west compressional thickening ${ }^{3,4}$. Furthermore, Lower Eocene sedimentary sequences in the Minami Daito basin, which predate Izu-Bonin-Mariana inception, are clast-free mudstone ${ }^{5}$. Basalt sills intercalated with these sediments are alkaline intraplate types lacking subduction zone input, consistent with a rifting environment ${ }^{6}$. This lack of evidence for compression of pre-Izu-Bonin-Mariana basement, coupled with the rifting and seafloor spreading accompanying the earliest arc products that we document ${ }^{1}$ is consistent with a spontaneous initiation model.

Both forced and spontaneous subduction inception models ${ }^{2}$ are oversimplified. The process is likely to be strongly threedimensional and probably propagates along-strike from an extant subduction system $^{7}$. For the Izu-Bonin-Mariana system, northward propagation from a subduction zone on the southern boundary of the protoPhilippine Sea plate as the latter rotated clockwise is possible ${ }^{1}$. Juxtaposition of old, dense Pacific plate lithosphere against the relatively buoyant lithosphere of the Mesozoic to Lower Tertiary arcs could have been critical for the spontaneous nucleation of a new subduction zone ${ }^{8}$.
References

1. Arculus, R. J. et al. Nature Geosci. 8, 728-733 (2015).

2. Stern, R. J. Earth Planet. Sci. Lett. 226, 275-292 (2004)

3. Nishizawa, A., Kaneda, K., Katagiri, Y. \& Oikawa, M. Earth Planets Space 66, http://doi.org/bd4q (2014).

4. Ishihara, T. \& Koda, K. Island Arc 16, 322-337 (2007).

5. Higuchi, Y. et al. Island Arc 16, 374-393 (2007).

6. Hickey-Vargas, R. J. Geophys. Res. Solid Earth 103, 20963-20979 (1998)

7. McKenzie, D. P. in Island Arcs, Deep Sea Trenches and Back-Arc Basins Vol. 1 (eds Talwani, M. \& Pitman, W. C., III) 57-61 (Maurice Ewing Series, American Geophysical Union, 1977).

8. Leng, W. \& Gurnis, M. Geophys. Res. Lett. 42, 7014-7021 (2015).

Richard J. Arculus ${ }^{1 \star}$, Osamu Ishizuka ${ }^{2,3}$, Kara A. Bogus ${ }^{4}$, Michael Gurnis ${ }^{5}$, Rosemary Hickey-Vargas ${ }^{6}$, Mohammed H. Aljahdali? Alexandre N. Bandini-Maeder ${ }^{8}$, Andrew P. Barth' ${ }^{9}$ Philipp A. Brand $1^{1,10}$, Laureen Drab"1, Rodrigo do Monte Guerra12, Morihisa Hamada ${ }^{13}$, Fuqing Jiang ${ }^{14}$, Kyoko Kanayama ${ }^{15}$, Sev Kender ${ }^{16,17}$, Yuki Kusano ${ }^{15}, \mathrm{He} \mathrm{Li}^{18}$, Lorne C. Loudin ${ }^{19}$, Marco Maffione ${ }^{20}$, Kathleen M. Marsaglia ${ }^{21}$, Anders McCarthy ${ }^{22}$, Sebastién Meffre ${ }^{23}$, Antony Morris ${ }^{24}$, Martin Neuhaus ${ }^{25}$, Ivan P. Savov ${ }^{26}$, Clara Sena ${ }^{27}$, Frank J. Tepley III28, Cees van der Land ${ }^{29}$, Gene M. Yogodzinski ${ }^{30}$ and Zhaohui Zhang ${ }^{31}$ 'Research School of Earth Sciences, Australian National University, Canberra ACT 2601, Australia. ${ }^{2}$ Geological Survey of Japan/AIST, Central 7 1-1-1 Higashi, Tsukuba, Ibaraki 